\title{
Erosion and control options in the La Ciénega Microbasin in Malinaltepec, Guerrero, Mexico
}

\author{
Bailón-Miranda, Javier ${ }^{1}$; Bustamante-González, Angel ${ }^{2 *}$; Vargas-López, Samuel ${ }^{2}$, \\ Morales-Jiménez, Juan ${ }^{2}$; Casiano-Ventura Miguel A. ${ }^{2}$
}

\author{
${ }^{1}$ Universidad Intercultural del Estado de Guerrero. Carretera Tlapa-Marquelia km. 54, La Ciénega, \\ Malinaltepec, Guerrero. ${ }^{2}$ Colegio de Postgraduados, Campus Puebla, Santiago Momoxpan, San \\ Pedro Cholula, Puebla, México.
}

*Corresponding author:: angelb acolpos.mx

\begin{abstract}
Objective: To estimate the water erosion rate in the La Ciénega Microbasin in Malinaltepec, Guerrero, Mexico, and to evaluate control options.

Design/methodology/approach: Potential erosion rate, actual erosion rate, and erosion control were estimated using the Universal Soil Loss Equation (USLE) under three conservation practices: contour plowing, successive land terracing, and live terracing with vetiver grass (Chrysopogon zizanioides (L.) Roberty).

Results: High erosion potential is shown by $99.18 \%$ of the microbasin surface area. Due to vegetation, only $41 \%$ of the surface area demonstrates high or very high actual erosion, 53.6\% light, and 4.6\% moderate. A living barrier using vetiver is the only conservation practice, of those assessed, that effectively diminished erosion.

Study limitations/implications: The lack of accurate data on rain-induced erosion was a limiting factor in this study. Findings/conclusions: The La Ciénega Microbasin has a high risk of erosion and current erosion is a problem on agricultural land. The most effective option is living barriers using vetiver.
\end{abstract}

Keywords: Soil loss, USLE, living barriers, Poaceae.

\section{INTRODUCCIÓN}

In the Montaña rains. Studies for quantifying erosion in this region are nonexistent, although evidence of its significance can be seen in the high concentration of sediments found in runoffs caused by rain. 
To estimate erosion, the Universal Soil Loss Equation (USLE) was used, a model widely tested on a global level for diverse environmental and management conditions (Alewell et al., 2019; Mancino et al., 2016; Lin et al., 2016), with reliable results for Mexico (PradoHernández et al., 2017). The Universal Soil Loss Equation is used to estimate soil loss and to support in planning agricultural production (Renard et al., 1997). It estimates average soil loss from erosion per unit of surface and time. It uses physical and management parameters, expressed numerically for a specific site and multiplied to estimate the quantity of soil lost. The equation is expressed as: $A=R K L S C P$ (Devata et al., 2015). A is soil loss (t ha ${ }^{-1}$ ); $R$ is the erosivity factor (dependent on the rainfall's characteristics); $K$ is the soil's erodability (dependent on the soil's characteristics); $L S$ is the slope length and angle; $C$ is the factor for vegetation cover; and $P$ is the factor for management practices. In recent decades, to estimate parameters for the Universal Soil Loss Equation, Geographic Information Systems are widely used (Flores et al., 2003; Mihaiescu, 2013) through interpolation maps, mainly with the Kriging method, in order to apply the equation in the geographic information system (Tesfaye et al., 2018). This helps improve the planning process for soil conservation practices because they can be previously evaluated considering specific scenarios for plots and basins (Bravo et al., 2009). This study had the objective of estimating the water erosion rate in the La Ciénega Microbasin in Malinaltepec, Guerrero, Mexico, and assessing options for its control.

\section{MATERIALS AND METHODOS}

The study was carried out in the La Ciénega Microbasin (Figure 1), in Malinaltepec, Guerrero, Mexico. The microbasin has an extension of $91.75 \mathrm{~km}^{2}\left(17^{\circ} 9^{\prime}\right.$ $30^{\prime \prime}$ and $17^{\circ} 18^{\prime} 30^{\prime \prime} \mathrm{N}$, and $98^{\circ} 35^{\prime} 30^{\prime \prime}$ and $98^{\circ} 44^{\prime}$ W). Climate varies from temperate $[C(W 2)(w)]$ in the northern zone to semi-warm and warm $[A(C) w 2(w)$ and $A w 2(w)]$ in the southwestern zone. The existing soils are: eutric regosol, lithosol, dystric cambisol, and haplic phaeozem, with the first two predominating. Vegetation is pine-oak, oak-pine, oak, and mountain mesophyll forests, with induced pasture areas and agricultural plots.

To estimate average annual erosion, the Universal Soil Loss Equation (USLE) was used:

$$
A=R K L S C P
$$

Where: $A=$ Soil loss (ton*ha ${ }^{-1 *}$ year ${ }^{-1}$ ); $R=$ Rainfall erosivity factor (MJ mm*ha ${ }^{-1 *} h^{-1 *}$ year ${ }^{-1}$ ); $K=$ Soil erodability factor $\left(t^{\star} h a^{-1^{\star}} h\right)\left(M J ~ m m^{*} h a^{-1}\right) ; L=$ Slope length (dimensionless); $S=S l o p e$ angle (dimensionless); $C=$ Crop or vegetation cover factor (dimensionless); and $P=$ Management practices (dimensionless).

The potential erosion was estimated considering only the RKL S parameters of the USLE. To estimate the rainfall's erosivity ( $R$ Factor), a regression model was obtained for average annual precipitation (Pm) and altitude $(H)$, with data from 10 weather stations and a Digital Elevation Model with a $15 \mathrm{~m}$ resolution. The resulting equation was:

$$
P m=1375.163+0.410 H \quad R^{2}=0.791, p=0.001
$$

With the Raster Calculator tool from the ArcMap 10.3 program, rainfall erosivity and average annual precipitation per pixel were estimated using the equation reported by Cortés (1991) for the $V$ zone:

$$
R=3.4880 P-0.000188 P^{2}
$$

( $R$ is the annual El30, in $\mathrm{MJ} \mathrm{mm} / \mathrm{ha} \mathrm{hr;} P$ is annual rain, in $\mathrm{mm}$ ). Erodability ( $K$ Factor) was obtained from morphological, physical, and chemical characteristics of the soils in each soil unit (INEGI, 2014), considering the values reported by the FAO (1980). In the vector soil mapping, a field with the $K$ value was added and it was converted to raster format with a $15 \mathrm{~m}$ pixel resolution.

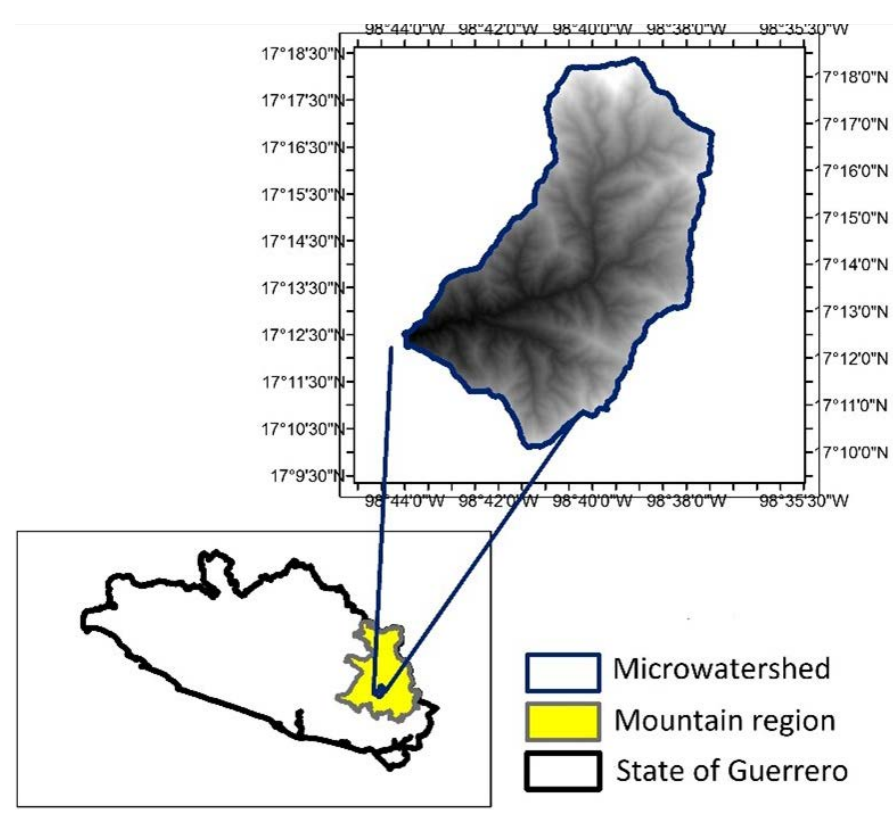

Figure 1. Location of the La Ciénega Microbasin. 
The LS factor was estimated based on a digital elevation model with a $15 \mathrm{~m}$ resolution. The $\mathrm{L}$ factor was calculated using the following formulas, according to Pastrana (2014):

$$
\begin{gathered}
L=(/ / 22.3)^{m} ; m=F /(1+F) ; F=(\operatorname{Sen} b / 0.0896) / \\
\left.\left[3(\operatorname{sen} b)^{0.08}+0.56\right] ; L_{(i, j)}=\left[\left(A_{(i, j)}+D^{2}\right)^{m+1}-A_{(i, j)}\right)^{m+1}\right] / \\
{\left[X^{m} * D^{m+2} *(22.3)^{m}\right]}
\end{gathered}
$$

Where: $L$ is the slope length factor; $l$ is the slope length in meters; $m$ is a parameter for the slope's steepness; $A_{(i, j)}$ $[\mathrm{m}]$ is the unit catchment area at a cell's opening; $D$ is the cell or pixel size, in this case with a $15 \mathrm{~m}$ resolution; $X$ is the form correction factor.

In ArcGis 10.3, the Raster Calculator tool was used by applying the previous formulas (Pastrana, 2014):

$$
\begin{gathered}
F=((\operatorname{Sin}(\text { Slope } * 0.01745) / 0.0896) / \\
(3 * \operatorname{Power}(\operatorname{Sin}(\text { Slope* } 0.01745), 0.8)+0.56))
\end{gathered}
$$

To estimate $m$, the formula $F /(1+F)$ was used, and the following expression was used for $L$ :

$$
\begin{gathered}
(\text { Power }(\text { Flow_acc }+625),(m+1)) \\
\text {-Power }(\text { Flow_acc, }(m+1)) / \\
\text { Power }(25,(m+2) \star \text { Power }(22.13, m))
\end{gathered}
$$

The $S$ factor was estimated considering the following formulas: $S_{(i, j)}=10.8$ Sen $b_{(i, j)}$ if $b_{(i, j)}$ is less than 0.09 ; $S_{(i, j)}=16.8$ Sen $b_{(i, j)}$ if $b_{(I, j)}$ is more than 0.09. The $S$ factor was estimated as:

$$
\begin{gathered}
\operatorname{Con}((\operatorname{Tan}(\text { Slope*0.01745)<0.09), } \\
(10.08 * \operatorname{Sin}(\text { Slope*0.01745) }+0.03), \\
(16.8 * \operatorname{Sin}(\text { Slope*0.01745) }-0.5))
\end{gathered}
$$

To estimate the $C$ factor (vegetation cover), six types of soil use were digitalized using Spot 5 images from Google Earth with a spatial pixel resolution of $2.5 \mathrm{~m}$. A C value was assigned for each type of soil (human settlements, pastures, natural forests, landslides, secondary vegetation, and croplands).
The scenarios considered for conservation and erosion control practices were: 1) Contour plowing, 2) Successive land terracing, and 3) Live terracing with vetiver grass (Chrysopogon zizanioides), assigning them $P$ values of $0.8,0.6$, and 0.01 , respectively.

\section{RESULTS AND DISCUSSION \\ Erosion potential of the microbasin}

The microbasin's erosion potential is high (Figure 2; Table 1). The majority of the surface area has an erosion potential greater than $299 \mathrm{t} \mathrm{ha}^{-1}$ year ${ }^{-1}$, which is characteristic for the vast majority of the national territory (Montes-León et al., 2011), in contrast to countries like Argentina where only $9.1 \%$ of its territory presents

\begin{tabular}{|c|c|c|c|c|}
\hline $\begin{array}{c}\text { Potential erosion } \\
\left(\mathrm{t} \mathrm{ha} \mathrm{h}^{-1} \mathrm{yr}^{-1}\right)\end{array}$ & Level & $\mathrm{km}^{2}$ & hectare & $\%$ \\
\hline $0-10$ & Low & 0.010575 & 1.0575 & 0.01 \\
\hline oct - 50 & Moderate & 0.039825 & 3.9825 & 0.04 \\
\hline $50-200$ & High & 0.7029 & 70.29 & 0.77 \\
\hline$>200$ & Very high & 91.006875 & 9100.6875 & 99.18 \\
\hline
\end{tabular}
erosion potential levels greater than $200 \mathrm{t} \mathrm{ha}^{-1}$ year ${ }^{-1}$ (Gaitán et al., 2017). This indicates a high risk of erosion in the whole microbasin if the vegetation is removed or if adequate soil conservation practices are not used in agricultural lands.

\section{Actual Erosion}

Of the microbasin's surface area, 53\% has light erosion (Figure 3; Table 2). This is associated with the presence of forests and other types of vegetation in more than half of the microbasin's area. However, strong erosion is
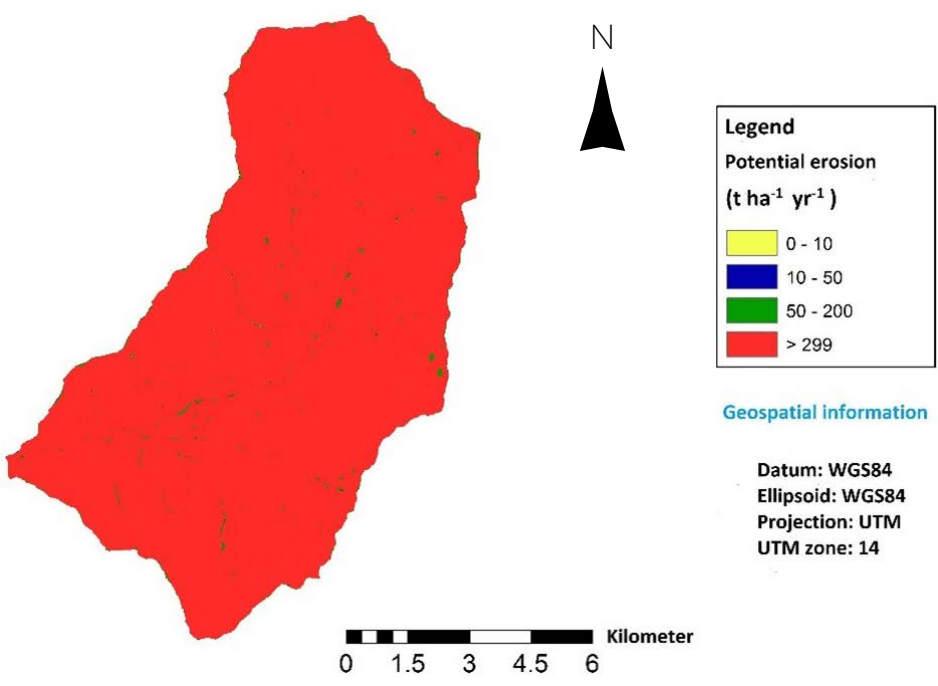

Geospatial information

Datum: WGS84 Ellipsoid: WGS84 Projection: UTM UTM zone: 14

Figure 2. Erosion potential of the La Ciénega Microbasin. 


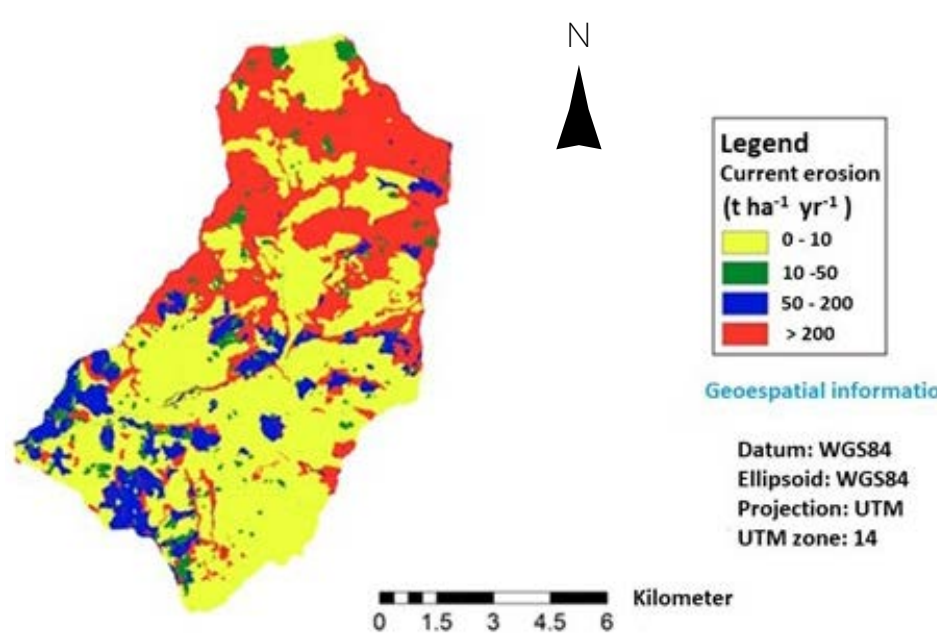

Figure 3. Actual erosion in the microbasin (2020).

\begin{tabular}{|c|c|c|c|c|}
\hline $\begin{array}{l}\text { Current erosion } \\
\left(\mathrm{t} \mathrm{ha} \mathrm{a}^{-1} \mathrm{yr}^{-1}\right)\end{array}$ & Level & $\mathrm{km}^{2}$ & hectare & $\%$ \\
\hline $0-10$ & Low & 49.15395 & 4915.4 & 53.6 \\
\hline $10-50$ & Moderate & 4.244175 & 424.4 & 4.6 \\
\hline $50-200$ & High & 8.991225 & 899.1 & 9.8 \\
\hline$>200$ & Very high & 29.29635 & 2929.6 & 32.0 \\
\hline
\end{tabular}

present in $32 \%$ of the microbasin, in lands of agricultural use and much degraded zones, with erosion rates higher than 200 t ha $^{-1}$ year $^{-1}$. This constitutes a significant area where soil conservation practices should be promoted.

\section{Erosion control options}

Contour plowing and terracing practices, considered to be mechanical practices, have a very low impact on erosion reduction (Figure 4, Table 3). Incidence on the erosion rate of zones of high and very high actual erosion is low. Living barriers using vetiver will significantly reduce erosion in agricultural lands with high and very high actual erosion (Figure 5). The effectiveness of live vetiver hedges has been documented, reporting reductions of 56.2 to $87.9 \%$ in steep terrain (Donjadee et al., 2010).

Vetiver is currently being tested in the microbasin (Figure 6). The plant can adapt to a diverse range of environmental conditions and because of its growth type, it does not compete with crops and does not become a weed (National Research Council, 1993). Live vetiver hedges accumulate soil and avoid the loss of soil productivity and the decrease of crop yields due to soil erosion (Oshunsanya, 2013). This suggests that it can be accepted by rural producers in the microbasin.

\section{CONCLUSIONS}

The erosion potential in the La Ciénega Microbasin is high, with potential erosion rates greater than $299 \mathrm{t} \mathrm{ha}^{-1}$ year $^{-1}$. Actual erosion in almost half of the microbasin surface area (53.6\%) is light, due to the presence of primary forest. Meanwhile, very high erosion (32\% of the microbasin area)
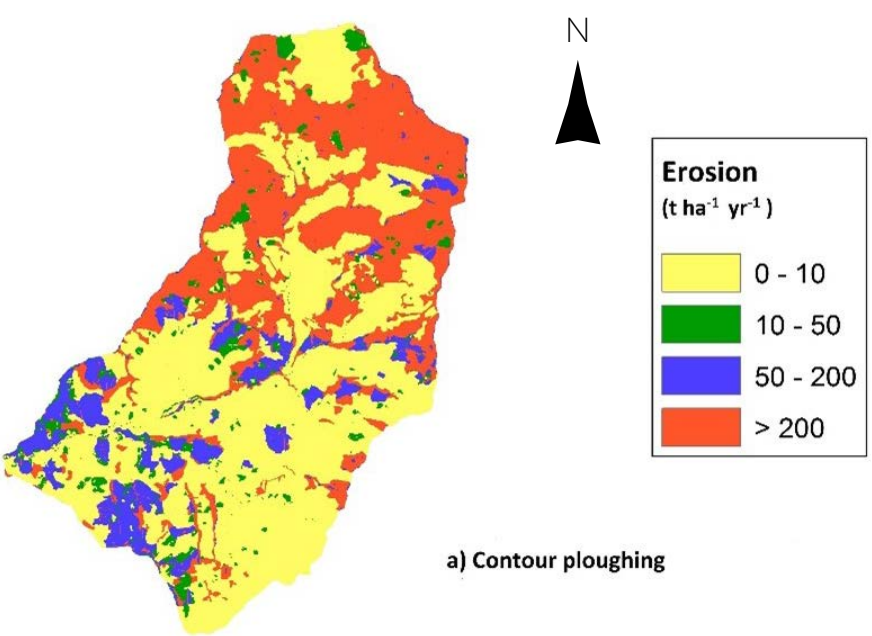

a) Contour ploughing

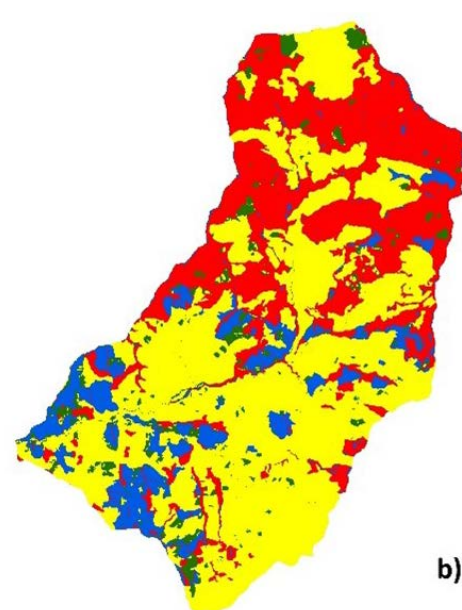

$\Lambda$

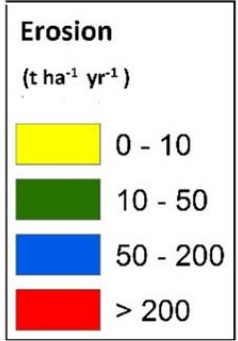

b) Contour terraces

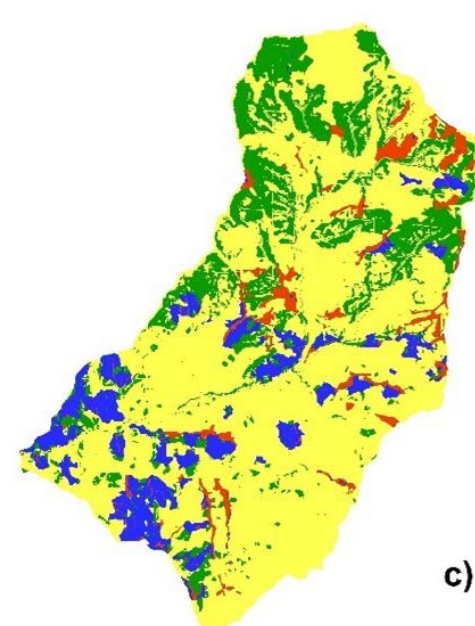

$\Lambda$

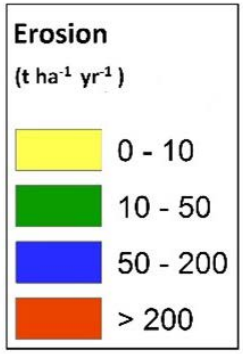

Figure 4. Maps of estimated erosion using contour plowing practices, contour terracing, and live vetiver barriers. 


\begin{tabular}{|c|c|c|c|c|c|c|c|c|c|}
\hline \multirow{2}{*}{$\begin{array}{l}\text { Erosion } \\
\text { t ha-yr }\end{array}$} & \multirow{2}{*}{ Level } & \multicolumn{2}{|c|}{ Current condition } & \multicolumn{2}{|c|}{ Contour ploughing } & \multicolumn{2}{|c|}{ Contour terrace } & \multicolumn{2}{|c|}{ Terrace with vetiver } \\
\hline & & $\mathrm{km}^{2}$ & $\%$ & $\mathrm{~km}^{2}$ & $\%$ & $\mathrm{~km}^{2}$ & $\%$ & $\mathrm{~km}^{2}$ & $\%$ \\
\hline $10-50$ & Moderate & 4.24 & 4.6 & 4.27 & 4.7 & 4.31 & 4.7 & 17.73 & 19.3 \\
\hline $50-200$ & High & 8.99 & 9.8 & 9.12 & 9.9 & 9.36 & 10.2 & 8.67 & 9.5 \\
\hline
\end{tabular}

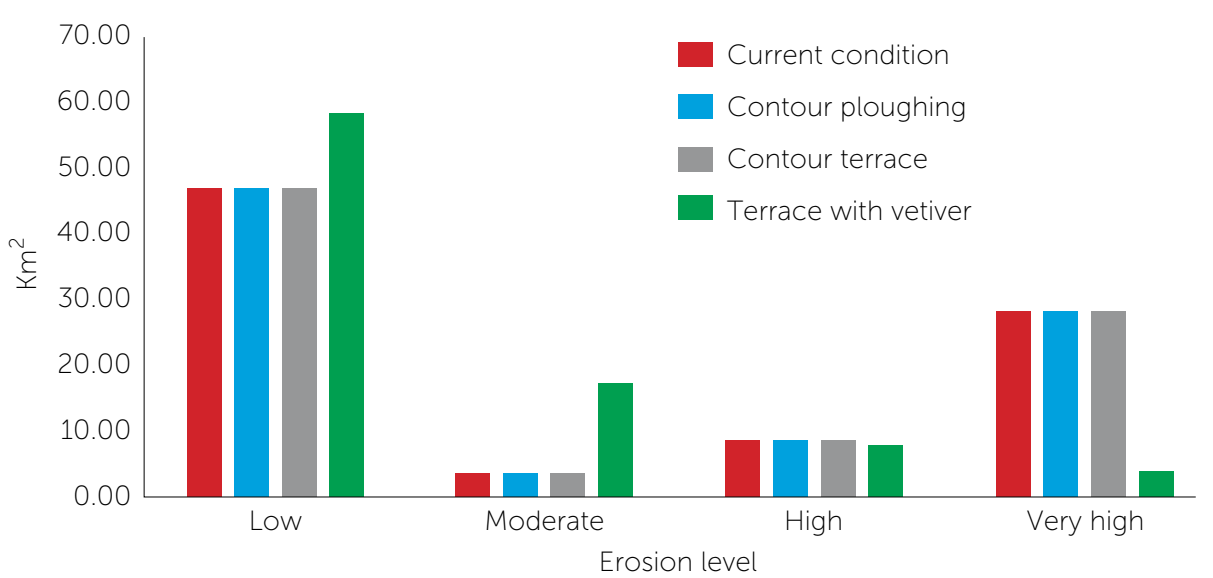

Figure 5. Microbasin area and degree of erosion for scenarios of conservation practices.
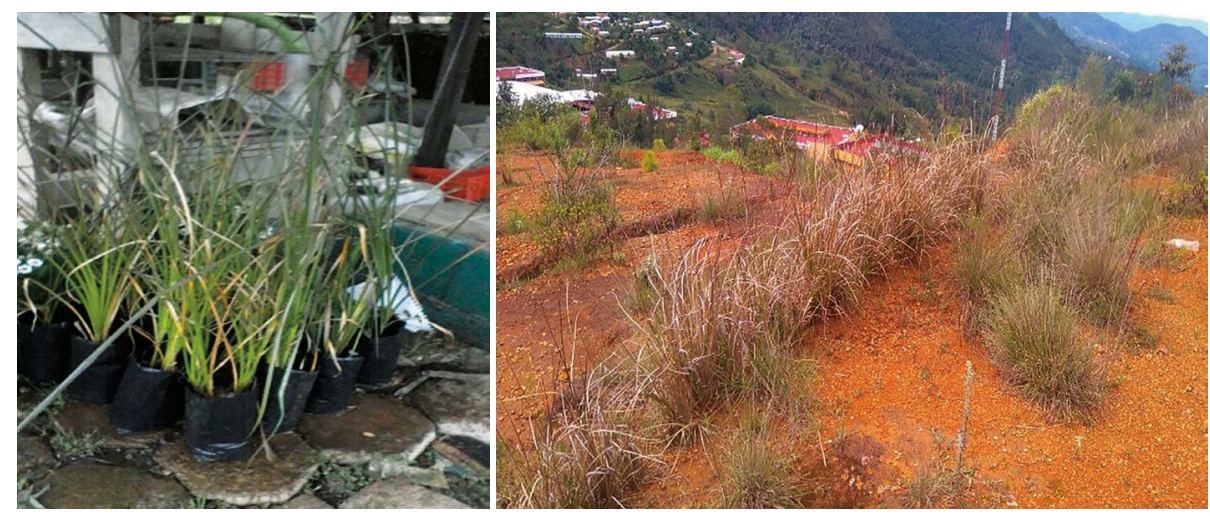

Figure 6. Vetiver plant (Chrysopogon zizanioides (L.) Roberty) in a nursery and in lands in the microbasin.

is associated with agricultural activities and degraded areas. Of the three management scenarios evaluated for water erosion control, both contour plowing and successive land terracing do not result in reducing soil loss at an acceptable level. On the other hand, the use of live barriers with vetiver hedges (Chrysopogon zizanioides) in agricultural lands and degraded zones results in a $27.1 \%$ reduction in erosion within the very high to moderate and light categories.

\section{REFERENCES}

Alewell, C.; Borrelli, P.; Meusburger, P.; \& Panagos, P. (2019). Using the USLE: Chances, challenges, and limitations of soil erosion modelling. International Soil and Conservation research 7: 203-225

Bravo, M.; Mendoza, M.E.; y Medina, L.E. (2009). Escenarios de erosión bajo diferentes manejos agrícolas en la cuenca del lago de Zirahuén, Michoacán, México. Investigaciones Geográficas 68: 73-84.
Cortés, H.G. (1991). Caracterización de la erosividad de la lluvia en México utilizando métodos multivariados. Tesis de Maestria en Ciencias. Colegio de Postgraduados. Montecillos. México. 168 pp.

Devata, C.P.; Deshpande, V.; \& Renukaprasad, M.S. (2015). Estimating of soil loss using USLE model for Kulhan watershed, Chattisgarh- A case study. Aquatic Procedia 1: 1429-1436.

Donjadee, S.; Clemente, R.S.; Tingsanchali, T.; \& Chinnarasri, C. (2010). Effects of vertical hedge interval of vetiver grass on erosion on steep agricultural lands. Land Degradation \& Development 21. 219-227.

FAO. 1980. Metodología provisional para la evaluación de la degradación de suelos. Roma, Italia. $86 \mathrm{p}$

Flores, H.E., M. Martínez, J.L. Oropeza, E. Mejía y R. Carrillo. 2003. Integración de la EUPS a un SIG para estimar la erosión hídrica del suelo en una cuenca hidrográfica de Tepatitlán, Jalisco, México. Terra 21(2): 233-244.

Gaitán, J.; Navarro, M.F.; Tenti, L.V.; Pizarro, M.J.; Carfagno, P.; y Rigo, S. (2017). Estimación de la pérdida de suelo por erosión hídrica en la República Argentina. INTA Ediciones. Buenos Aires, Argentina.

INEGI. (2014). Conjunto de datos vectoriales edafológicos escala 1 : 250000 Serie 11.

Lin, B.S.; Thomas, K.; \& Chen, C.K. (2016). Evaluation of soil erosion risk for watershed management in Shenmu watershed, central Taiwan using USLE model parameters. Paddy and Water Environment 14: 12-43.

Mancino, G.; Nolé, A.; \& Ferrar, A. (2016). In-between forest expansion and cropland decline: A revised USLE model for soil erosion risk under land-use change in a Mediterranean region. Ecological Indicators 71: 544-550. 
Mihaiescu, T. (2013). Assessment of soil erosion risk in Fizes river catchment using USLE model and GIS. ProEnvironment 6: 595-599.

Montes-León, M.A.L.; Uribe-Alcántara, E.M., y García-Celis, E. (2011). Mapa nacional de erosión potencial. Tecnología y Ciencia del Agua 11,1, 5-17.

National Research Council. (1993). Vetiver grass: a thing green line against erosion. National Academy Press. Washington, D.C. 171 p.

Pastrana, O.V. 2014. Determinación de la erosión hídrica potencial y actual a través de los sistemas de información geográfica. Tesis Ingeniero Agrónomo Especialista en Irrigación. Universidad Autónoma Agraria Antonio Narro.114 p

Prado-Hernández, J.V.; Rivera-Ruiz, P.; de León-Mojarro, B.; Carrillo-García, A.; y Martínez-Ruiz, A. (2017). Calibración de los modelos de pérdidas de suelo USLE y MUSLE en una cuenca forestal de México: Caso el Malacate. Agrociencia 51: 265-248.

Oshunsanya, S.O. (2013). Spacing effects of vetiver grass (Vetiveria nigritana Stapf) hedgerows on soil accumulation and yields of maize-cassava intercropping system in Southwest Nigeria. Catena 104: $120-126$

Renard, K.G., G.R. Foster, G.A. Weesies, D.K. McCool y D.C. Yoder (coords.). 1997. Predicting soil erosion by water: A guide to conservation planning with the revised Universal Soil Loss Equation (RUSLE). U.S. Department of Agriculture, Agriculture Handbook No. 703, 404 p.

Tesfaye, G.; Debebe, Y.; \& Fikirie, K. (2018). Soil erosion risk assessment using GIS base USLE model for soil and water conservation planning in Somodo watershed south west Etipia. International Journal of Envrionmental \& Agriculture Research.

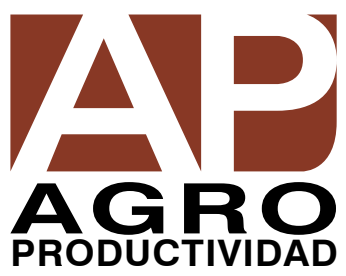

